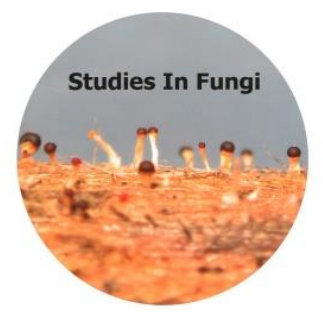

Studies in Fungi 3(1): 241-247 (2018) www.studiesinfungi.org ISSN 2465-4973

Article

Doi 10.5943/sif/3/1/24

Copyright $(\mathcal{O}$ Institute of Animal Science, Chinese Academy of Agricultural Sciences

\title{
Effects of environmental factors and host characteristics on diversity and distribution of wood-rotting fungi of Mount Puliebadze, Nagaland
}

\section{Chuzho K* and Dkhar MS}

Microbial Ecology Laboratory, Centre for Advanced Studies in Botany, North-Eastern Hill University, Shillong campus 793022, Meghalaya, India

Chuzho K, Dkhar MS 2018 - Effects of environmental factors and host characteristics on diversity and distribution of wood-rotting fungi of Mount Puliebadze, Nagaland. Studies in Fungi 3(1), 241247, Doi 10.5943/sif/3/1/24

\begin{abstract}
The study on the effects of environmental factors and host characteristics on diversity and distribution of wood-rotting fungi Mount Puliebadze, Nagaland was carried out for a period of two successive years (January 2015 to December 2016). A total of 46 wood-rotting fungi belonging to 16 families were identified. The occurrence of wood-rotting fungi demonstrated a decreasing trend with increase in elevations and correlation between the two variables showed a strong negative correlation with Pearson's correlation coefficient (r) value of -0.993 . The zone with lowest elevation (zone 1) comprised maximum number of species (25 species) whereas the zone with highest elevation (zone 4) comprised minimum number of species (05 species). Highest species similarity percentage $(25.9 \%)$ was observed between zone 2 and 3. One way ANOVA showed significant variations between the occurrence of wood-rotting fungi with different seasons, light intensity, type of substrata and decay stage of wood. Shannon's diversity index ( $\left.\mathrm{H}^{\prime}\right)$ of zone 1 was highest $\left(\mathrm{H}^{\prime}=3.073\right)$ and that of zone 4 was lowest $\left(\mathrm{H}^{\prime}=1.242\right)$.
\end{abstract}

Key words - Correlation - ecology - elevation - Non-matric Multidimensional Scaling

\section{Introduction}

Wood-rotting fungi comprised a diverse group of macrofungi and are widely distributed under the divisions Basidiomycota, Ascomycota and a few from Myxomycota. They decompose complex organic polymers such as lignin, cellulose and hemicellulose of plant cell wall and are responsible for the release of nutrients and carbon from fallen woody debris (Berg \& Laskowski 2005, Senkowsky 2006). Diversity of wood-rotting fungi at a given forest stand depends on various environmental factors such as altitudinal and seasonal variation, the type of forest vegetation and different host characteristics such as type of host tree species, type of substrata and decay stages of wood (Hattori 2005, Robledo \& Renison 2010, Pouska et al. 2011).

Northeast India comprises of eight culturally diverse states and a major part of Northeast India, is under the Indo-Burma Biodiversity Hotspot region of the world (Moghe 2011). Nagaland is one of the mountainous states of Northeast where majority of the forest still remain unexplored. Mount Puliebadze is a part of Japfu Range which includes Mount Japfu, the 2nd highest mountain peak in Nagaland and is located in Kohima district (Sustainable Development Forum, Nagaland 
2013). Studies on wood-rotting fungi of Nagaland have been performed for the past five years (Chuzho et al. 2017, Chuzho \& Dkhar 2017). The present study was carried out to understand effects of environmental factors and host characteristics on diversity and distribution of woodrotting fungi of Mount Puliebadze, Nagaland along an elevation gradient.

\section{Materials \& Methods}

Survey and collection of wood-rotting fungi was performed from January 2015 to December 2016 on seasonal basis (spring: April to May, summer: July to September, autumn: October to November and winter: December to February). The forest stand was divided into four zone viz. zone 1 (1640-1800msl), zone 2 (1810-2000msl), zone 3 (2010-2200msl) and zone 4 (2210$2318 \mathrm{msl}$ ). Line transect method was used for sampling fruiting bodies (Mueller et al. 2004).

Identification was carried out according to standard macroscopic and microscopic characters through standard monographs (Bakshi 1966, Ryvarden \& Johansen 1980, Nunez \& Ryvarden 2000, 2001) and also form Databases - Fungi from India (2012-'16). The current scientific names and taxonomic status of all the species were confirmed from Mycobank (www.mycobank.org). Method by Pouska et al. (2011) was followed for differentiating the various stages of wood decay. Five stages of wood decay were recognized: decay stage I (newly fallen woods; knife penetrates only a few millimeters into the wood), decay stage II (knife penetrates $1-2 \mathrm{~cm}$ into the wood), decay stage III (knife penetrates $3-5 \mathrm{~cm}$ into the wood), decay stage IV (knife penetrates $6-10 \mathrm{~cm}$ into the wood) and decay stage V (wood very old, easily disintegrates when lifting). The occurrence of wood-rotting fungi on different types of substrata (logs, twigs, stump), surface of substrata (bark, sapwood) and type of host trees (hardwood, softwood and bamboo culms) were recorded at the time of sampling.

One way ANOVA was done to see if there is significant variation between the occurrence of wood-rotting fungi with different seasons, light intensity, type of substrata and decay stage of wood. Similarity in species compositions between the four different zones was determined using Jaccard Similarity index (J). Non-matric multidimensional scaling (nMDS) ordination was used to plot the similarities in species composition in different zones and seasons. Species diversity was calculated using Shannon's diversity index ( $\left.\mathrm{H}^{\prime}\right)$. All the statistical analyses were performed using SPSS 16 software.

\section{Results}

A total of 46 wood-rotting fungi belonging to 16 families were identified. Maximum number of species belonged to Polyporaceae (14 species). Wood-rotting fungi belonging to Hymenochaetaceae and Polyporaceae were found in all the 4 zones. The zone with lowest elevation (zone 1) comprised 25 species (54\%) whereas the zone with highest elevation (zone 4) comprised only 5 species $(10.8 \%)$. The occurrence of wood-rotting fungi showed an increasing trend with increase in elevations and correlation between the two variables showed a strong negative correlation with Pearson's correlation coefficient (r) value of -0.993 . This implied that diversity of wood-rotting fungi was higher in lower altitudes as compared to higher altitudes. Highest species similarity percentage (25.9\%) was observed between zone 2 and 3, which was confirmed by nMDS ordination plot.

Diversity and distribution of wood-rotting fungi varied with different seasons, light exposure, type and surface of substrata and decay stages of wood effect. Highest number of wood-rotting fungi was recorded during summer season. There was similarity in species composition in different seasons and nMDS ordination plot confirmed this finding. Maximum similarity in species composition was observed between summer and autumn seasons. The occurrence of wood-rotting fungi along the four zones and nMDS ordination plots are presented in Fig. 1. Majority of woodrotting fungi was found on the substrata which were exposed to sunlight. Logs, barks and decay stage III seemed to be the suitable habitat for the formations of sporocarps of majority of the species (Table 1). Maximum number of species was found growing on hardwood debris and no species was found growing on softwood debris. 
One way ANOVA showed that there is a significant variation for the analyses of occurrence of wood-rotting fungi with different seasons, light intensity, type of substrata and decay stages of wood. Shannon's diversity index $\left(\mathrm{H}^{\prime}\right)$ of zone 1 was highest $\left(\mathrm{H}^{\prime}=3.073\right)$ and that of zone 4 was lowest $\left(\mathrm{H}^{\prime}=1.242\right)$.
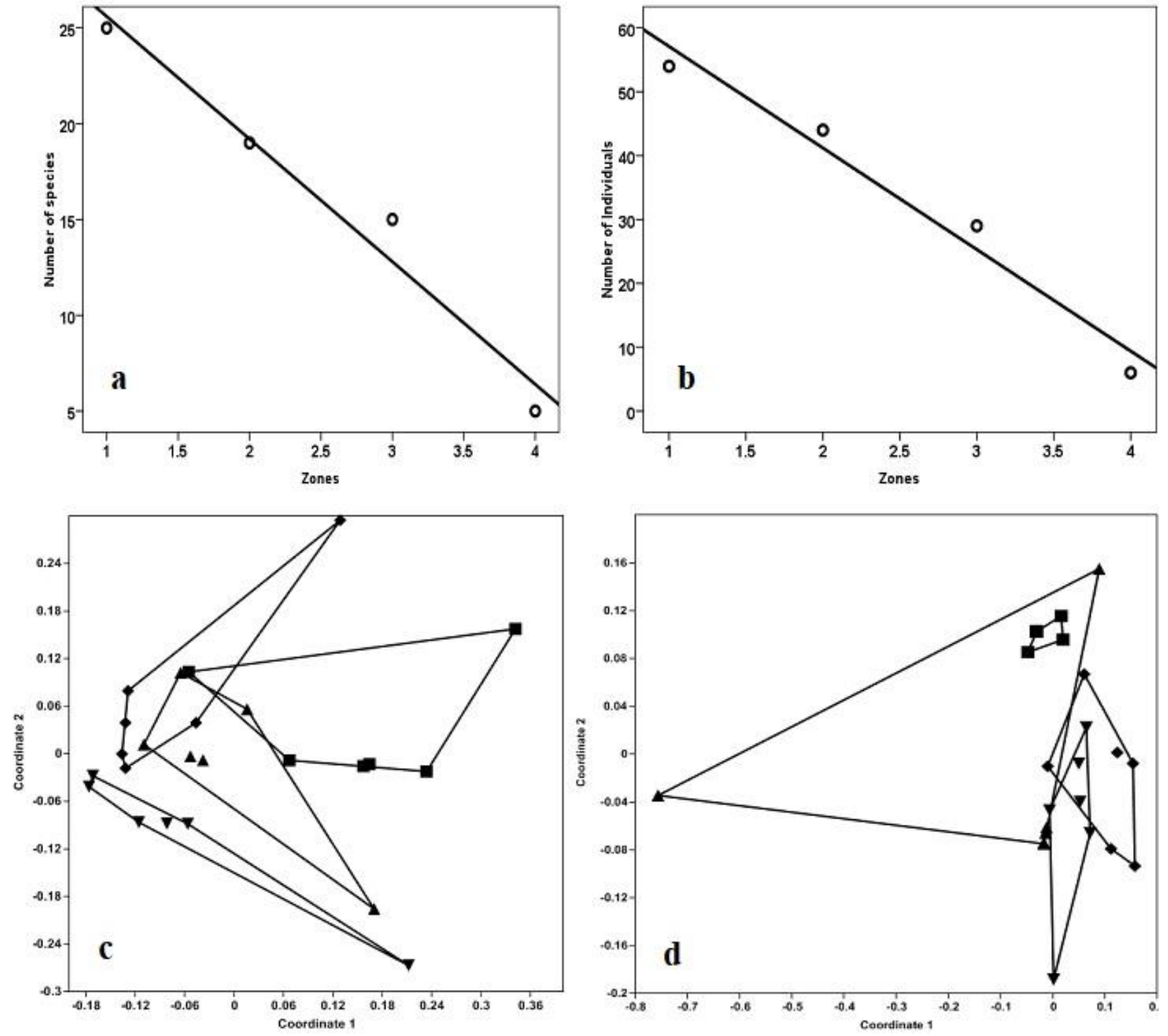

Fig. 1 - a Total number of species at different zones. b total number of individuals at different zones. c nMDS ordination diagram of species composition in different zones (zone 1 - filled inverted triangle; zone 2 - filled diamond; zone 3 - filled triangle, and zone 4 - filled square) with zone 2 and zone 3 showing maximum similarity. d nMDS ordination diagram of different seasons (spring - filled triangle; summer - filled inverted triangle; autumn - filled diamond and winter filled square) with summer and winter seasons showing maximum similarity.

\section{Discussion}

Highest number of the wood-rotting fungi is classified under Polyporaceae. The dominance of this family was also reported by Sailo (2010), Lyngdoh \& Dkhar (2014a, b), Lyngdoh 2014 from north-east India. The occurrence of wood-rotting fungi showed an increasing trend with increase in elevations and correlation between the two variables showed a strong negative correlation This demonstrated that diversity of wood-rotting fungi was higher in lower altitudes as compared to higher altitudes. Similar findings were also reported by Kuffer \& Senn-Irlet (2005), Yamashita et 
al. (2014) where the number of species recorded in lower elevations was greater than those recorded from higher elevations. However, a study by Robledo \& Renison (2010) in Argentina showed a contrary result where altitude was positively related to species richness.

Diversity and distribution of wood-rotting fungi varied with different seasons, light exposure, type and surface of substrata and decay stages of wood effect. The effects of various environmental factors on the diversity and distribution of wood-rotting fungi was reported by several authors (Kodsueb et al. 2008, Gilbertoni et al. 2007, Kenney et al. 2006, Boddy \& Heilmann-Clausen 2008, Bassler et al. 2010). Growth of wood-rotting fungi is positively imparted by rainfall and thus more fungi were reported to be present during wet season (Zhou \& Hyde 2002). The preference of woodrotting fungi to certain decay stages of wood particularly to wood at decay stage III was observed during our study. According to Pouska et al. 2011, majority of the species favored intermediate stage of decaying wood (stage III) which supports our results. Maximum number of species was found growing on hardwood debris. This is because the forest stand is dominated by hardwoods such as Alnus nepalensis, Castanopsis indica, Prunus species Rhododendron arboreum and Quercus species. The only softwood tree recorded from the study area was Cryptomeria japonica and furthermore, diversity and distribution of wood-rotting fungi depends on the type of vegetation (Hattori 2005).

Studies on wood-rotting fungi of Nagaland have been done only for the past five years (Chuzho et al. 2017, Chuzho \& Dkhar 2017). Hence, a detailed study is recommended for a complete documentation of wood-rotting fungi in forests of Nagaland.

Table 1 List of species with their code, zones of occurrence, types of substrata, surface of substrata, decay stages of wood and light exposure.

\begin{tabular}{|c|c|c|c|c|c|c|}
\hline $\begin{array}{l}\text { Sl. } \\
\text { no. }\end{array}$ & Species & Zone & $\begin{array}{c}\text { Type of } \\
\text { substrata }\end{array}$ & $\begin{array}{c}\text { Surface } \\
\text { of } \\
\text { substrata }\end{array}$ & $\begin{array}{l}\text { Decay } \\
\text { stage }\end{array}$ & $\begin{array}{c}\text { Light } \\
\text { expo- } \\
\text { sure }\end{array}$ \\
\hline 1 & Agaricus squarrosus & 1 & $\mathrm{Li}$ & $\mathrm{Sp}$ & I & Ex \\
\hline 2 & Antrodiella zonata & 1 & St & $\mathrm{Br}$ & II & Ex \\
\hline 3 & Auricularia auricula-judae & 1 & Lo & $\mathrm{Sp}$ & III & Ex, Sh \\
\hline 4 & A. polytricha & 1,3 & Lo, Tw & $\mathrm{Sp}$ & II, III & Ex \\
\hline 5 & Bjerkandera adusta & 1 & Lo & $\mathrm{Br}$ & II & Ex \\
\hline 6 & Coprinellus micaceus & 1,2 & Lo & $\mathrm{Br}$ & III & Ex \\
\hline 7 & Coriolopsis gallica & 1 & Lo & $\mathrm{Sp}$ & II & Ex \\
\hline 8 & C. telfarii & 1 & Lo & $\mathrm{Sp}$ & III & Ex \\
\hline 9 & Cyathus striatus & 1 & Tw & $\mathrm{Sp}$ & III & Ex \\
\hline 10 & Dacrymyces plamatus & 4 & Lo & $\mathrm{Br}$ & II & Ex \\
\hline 11 & Daldinia concentrica & $1,2,3$ & Lo & $\mathrm{Br}$ & III & Ex, Sh \\
\hline 12 & Deflexula subsimplex & 2 & Lo & $\mathrm{Br}$ & III & Ex \\
\hline 13 & Ganoderma applanatum & 3 & $\mathrm{Li}, \mathrm{Lo}$ & $\mathrm{Br}$ & I, II & Ex \\
\hline 14 & Hexagonia tenuis & 1 & $\mathrm{Tw}$ & $\mathrm{Br}$ & II & Ex \\
\hline 15 & Hymenochaete cyclomellata & 2 & Lo & $\mathrm{Br}$ & III & Ex \\
\hline 16 & H. tabacina & 1,2 & St, Tw & $\mathrm{Br}$ & II & Ex \\
\hline 17 & Hypoxylon fuscum & 3 & Tw & $\mathrm{Sp}$ & III & Ex \\
\hline 18 & Irpex lacteus & 1 & $\mathrm{Tw}$ & $\mathrm{Br}$ & III & Ex \\
\hline 19 & Jackrogersella cohaerens & 3 & $\mathrm{Tw}$ & $\mathrm{Br}$ & II, III & Ex \\
\hline 20 & Jackrogersella sp. 1 & 2 & Tw & $\mathrm{Br}$ & II & Sh \\
\hline 21 & Kretzschmaria deusta & 2 & Lo & $\mathrm{Br}$ & IV & Ex \\
\hline 22 & Lentinus fasciatus & 2 & St & $\mathrm{Sp}$ & III & Ex \\
\hline 23 & Lopharia cinerascens & 1 & $\mathrm{Tw}$ & $\mathrm{Br}, \mathrm{Sp}$ & III & Ex, Sh \\
\hline 24 & Microporus affinis & 4 & Lo, Tw & $\mathrm{Sp}$ & III & Ex \\
\hline 25 & M. vernicipes & 2,3 & $\mathrm{Tw}$ & $\mathrm{Br}$ & III & Ex \\
\hline
\end{tabular}


Table 1 Continued.

\begin{tabular}{|c|c|c|c|c|c|c|}
\hline $\begin{array}{l}\text { Sl. } \\
\text { no. }\end{array}$ & Species & Zone & $\begin{array}{c}\text { Type of } \\
\text { substrata }\end{array}$ & $\begin{array}{c}\text { Surface } \\
\text { of } \\
\text { Substrata }\end{array}$ & $\begin{array}{c}\text { Decay } \\
\text { stage }\end{array}$ & $\begin{array}{c}\text { Light } \\
\text { expo- } \\
\text { sure }\end{array}$ \\
\hline 26 & M. xanthopus & 1,3 & Lo, Tw & $\mathrm{Sp}$ & II, III & Ex \\
\hline 27 & Phellinus gilvus & 2 & Lo & $\mathrm{Sp}$ & III & Ex \\
\hline 28 & P. wahlberghii & $2,3,4$ & Lo & $\mathrm{Br}$ & I, IV & Ex \\
\hline 29 & Pleurotus ostreatus & 1 & Lo & $\mathrm{Sp}$ & III & Ex \\
\hline 30 & Porodisculus pendulus & 3 & Tw & $\mathrm{Br}$ & III & Ex \\
\hline 31 & Pycnoporus sanguineus & 1 & Lo & $\mathrm{Br}$ & III & Ex \\
\hline 32 & Schizophyllum commune & 1 & $\mathrm{Tw}, \mathrm{Cu}$ & $\mathrm{Sp}$ & III & Ex \\
\hline 33 & Stemonitis splendens & 1 & Lo & Sp & IV & Sh \\
\hline 34 & Stereum hirsutum & 2,3 & Lo & $\mathrm{Br}$ & II, III & Ex \\
\hline 35 & S. ostrea & $1,2,3$ & Lo & $\mathrm{Br}$ & III & Ex \\
\hline 36 & Trametes hirsuta & 1 & $\mathrm{Lo}, \mathrm{Cu}$ & $\mathrm{Br}$ & II & Ex \\
\hline 37 & T. lactinea & 1,2 & $\mathrm{Li}, \mathrm{St}$ & $\mathrm{Br}$ & II & Ex \\
\hline 38 & T. pubescens & 4 & Lo & $\mathrm{Sp}$ & IV & Ex \\
\hline 39 & T. versicolor & 1,2 & Lo, St, Tw & $\mathrm{Br}, \mathrm{Sp}$ & II, III & Ex \\
\hline 40 & Trichaptum byssogenum & 3,4 & Lo, Tw & $\mathrm{Br}, \mathrm{Sp}$ & II, III & Ex, Sh \\
\hline 41 & Xylaria apiculata & 2,3 & $\mathrm{Tw}$ & $\mathrm{Sp}$ & III, IV & $\mathrm{Ex}, \mathrm{Sh}$ \\
\hline 42 & X. hypoxylon & 2 & Lo & $\mathrm{Br}$ & IV & Ex \\
\hline 43 & $X$. longipes & 1 & Lo & $\mathrm{Sp}$ & IV & Ex \\
\hline 44 & $X$. polymorpha & $1,2,3$ & Lo, St & $\mathrm{Br}, \mathrm{Sp}$ & III, IV & $\mathrm{Ex}, \mathrm{Sh}$ \\
\hline 45 & Xylobolus frustulatus & 2 & Lo, Tw & $\mathrm{Sp}$ & IV, V & $\mathrm{Ex}$ \\
\hline 46 & X. subpileatus & 3 & $\mathrm{Li}$ & $\mathrm{Sp}$ & I & Ex \\
\hline
\end{tabular}

*1: Zone 1; 2: Zone 2; 3: Zone 3; 4: Zone 4; Li: Living trees, Lo: Logs; St: Stumps; Tw: Twigs; Cu: Bamboo culms; Br: Bark; Sp: Sapwood; I: Decay stage I; II: Decay stage II; III: Decay stage III; IV: Decay stage IV; V: Decay stage V; Ex: Exposed to sunlight; Sh: Under shaded condition.

\section{Conclusion}

This study gives gave an insight into the altitudinal distribution, seasonal variations and substrate preferences of wood-rotting fungi. It can be concluded that species diversity of woodrotting fungi decreased with increase in elevation. Logs, twigs and wood decay stage III combined with adequate macro-environmental factors provide essential habitat for the formation and growth of the wood-rotting fungi. More intensive study on wood-rotting fungi of Nagaland will further unveil many interesting and unexplored wood-rotting fungi of the region.

\section{Acknowledgements}

The authors sincerely thanked Prof. N.S.K. Hrash (Rtd. Scientist G) and Dr. Manoj Kumar (FRI, Dehradun) for helping in identification of the species, Department of Botany, North-Eastern Hill University, Meghalaya for providing necessary laboratory requirements. The first author also thanked University Grants Commission, New Delhi and Ministry of Tribal Affairs, Govt. of India for financial support in the form of NFHE-ST Fellowship.

\section{References}

Bakshi BK. 1966 - Indian Polyporaceae (on trees and timber). Indian Council of Agricultural Research, New Delhi, pp. 20-246.

Bassler C, Muller J, Dziock F, Brandl R. 2010 - Effects of resource availability and climate on the diversity of wood-decaying fungi. Journal of Ecology 98, 822-832.

Berg B, Laskowski R. 2005 - A guide to carbon and nutrient turnover. Advances in Ecological Research 38, 1-428. 
Boddy L, Heilmann-Clausen J. 2008 - Basidiomycete community development in temperate angiosperm wood. British Mycological Society Symposia Series, Elsevier Ltd.

Chuzho K, Dkhar MS, Lyngdoh A. 2017 - Wood-rotting fungi in two forest stands of Kohima, North-east India - a preliminary report. Current Research in Environmental and Applied Mycology 7, 15-21.

Chuzho K, Dkhar MS. 2017 - Diversity, ecology and biogeography of the family polyporaceae along an altitudinal gradient in forests of Nagaland. International Journal of Current Research in Life Sciences 6, 754-760.

Databases - Fungi from India (htpp://www.fungifromindia.com Accessed March 20 ${ }^{\text {th }} 2018$ )

Gilbertoni TB, Santos PJP, Cavaleanti AMQ. 2007 - Ecological aspects of Aphyllophorales in the Atlantic rain forest in North Brazil. Fungal Diversity 25, 49-67.

Hattori T. 2005 - Diversity of wood-inhabiting polypores in temperate forest with different vegetation types in Japan. Fungal Diversity 18, 73-88.

Kenney N, Brodic E, Connoly J, Clipson N. 2006 - Seasonal influences on fungal community structure in unimproved and improved upland grassland soils. Canadian Journal of Microbiology 52, 689-694.

Kodsueb R, McKenzie EHC, Lumyong S, Hyde KD. 2008 - Diversity of saprobic fungi on Magnoliaceae. Fungal Diversity 30, 37-53.

Kuffer N, Senn-Irlet B. 2005 - Diversity and ecology of wood-inhabiting aphyllophoroid basidiomycetes on fallen woody debris in various forest types in Switzerland. Mycological Progress 4, 77-86.

Lyngdoh A. 2014 - Diversity of wood-rotting macrofungi of East Khasi Hills and decay potential of some selected species. Ph. D. Thesis. North Eastern Hill University, Shillong, India.

Lyngdoh A, Dkhar MS. 2014a - First report of two wood-rotting fungi, Cyclomyces fuscus and Humphreya coffeatum, form India. Journal of New Biological Reports 3, 25-28.

Lyngdoh A, Dkhar MS. 2014b - Wood-rotting fungi in East Khasi Hills of Meghalaya, Northeast India, with special reference to Heterobasidion perplexa (a rare species - new to India). Current Research in Environmental \& Applied Mycology 4, 117-124.

Moghe G. 2011 - Biodiversity hotspots on India (www.biodiversityofindia.org Accessed August $\left.6^{\text {th }} 2018\right)$

Mueller GM, Gerald FB, Mercedes SF. 2004 - Biodiversity of fungi: Inventory and monitoring methods. Elsevier Academic Press, pp. 106-172.

Mycobank databases - (http://www.mycobank.org Accessed 20 March 2018).

Nunez M, Ryvarden L. 2000 - East Asian Polypores - Volume 1 (Ganodermataceae and Hymenochaetaceae). Synopsis fungorum 13. Funfiflora, Oslo, pp. 28-168.

Nunez M, Ryvarden L. 2001 - East Asian Polypores - Volume 2 (Polyporaceae).Synopsis fungorum 14. Funfiflora, Oslo, pp. 170-522.

Pouska V, Leps J, Svoboda M, Lepsova A. 2011 - How do log characteristics influence the occurrence of wood fungi in a mountain spruce forest? Fungal Ecology 4, 201-209.

Robledo GL, Renison D. 2010 - Wood-decaying polypores in the mountains of central Argentina in relation to Polylepis forest structure and altitude. Fungal Ecology 3, 178-184.

Ryvarden L, Johansen I. 1980 - A Preliminary Polypore Flora of East Africa. Fungiflora, Oslo, pp. 25-636.

Sailo JZ. 2010 - Studies on the wood rotting fungi of Meghalaya. Ph.D. Thesis. North Eastern Hill University, Shillong, India.

Senkowsky S. 2006 - Unearthing the secret lives of Alaska's mushrooms. Biological Sciences 56, 99-101.

Sustainable Development Forum, Nagaland 2013 - (sdfnagaland.org/puliebadze.html Accessed August $6^{\text {th }}$ 2018)

Yamashita S, Hattori T, Lee SS, Okabe K. 2014 - Estimating the diversity of wood-decaying polypores in tropical lowland rain forests in Malaysia: the effect of sampling strategy. Biodiversity Conservation 24, 393-406. 
Zhou D, Hyde D. 2002 - Fungal succession on bamboo in Hong Kong. Fungal diversity 10, 213227. 